\title{
Pertumbuhan Ekonomi, Belanja Modal dan Indeks Pembangunan Manusia: Panel Data Evidence Empat Kabupaten di Aceh
}

\author{
Nadlia Ariyati \\ Fakultas Ekonomi dan Bisnis Universitas Islam Negeri Ar-Raniry \\ e-mail: nadlia.ariyati@gmail.com \\ Fitria Rahayu \\ Fakultas Ekonomi dan Bisnis Universitas Islam Negeri Ar-Raniry \\ e-mail: rahayufitria250415@gmail.com \\ Nabila Rizqi Amalia \\ Fakultas Ekonomi dan Bisnis Universitas Islam Negeri Ar-Raniry \\ e-mail:nabilaamalia185@gmail.com \\ Suri Nurhaliza \\ Fakultas Ekonomi dan Bisnis Universitas Islam Negeri Ar-Raniry \\ e-mail: surinurhaliza@gmail.com \\ T. Muhammad Ghufran \\ Fakultas Ekonomi dan Bisnis Universitas Islam Negeri Ar-Raniry \\ e-mail:tmghufran@gmail.com \\ A. Rahmat Adi \\ Fakultas Ekonomi dan Bisnis Universitas Islam Negeri Ar-Raniry \\ e-mail:rahmatadi@gmail.com \\ Jalaluddin \\ Fakultas Ekonomi dan Bisnis Universitas Islam Negeri Ar-Raniry \\ e-mail:jalal.hmoto@gmail.com
}

\begin{abstract}
Abstrak
Penelitian ini bertujuan untuk menganalisis pengaruh pertumbuhan ekonomi dan belanja modal terhadap Indeks Pembangunan Manusia (IPM). Data yang digunakan adalah data panel empat kabupaten di Aceh terdiri dari kabupaten Aceh Tamiang, Gayo Lues, Aceh Tenggara, dan kabupaten Simeulu selama periode tahun 2011 2015. Data di analisis dengan menggunakan Regresi Panel, Panel Vector Autorgression (PVAR) dan Granger Causality Test. Penelitian menemukan bahwa pertumbuhan ekonomi berpengaruh positif dan signifikan terhadap Indeks Pembangunan Manusia, sebaliknya belanja modal berpengaruh positif namun tidak signifikan. IPM, pertumbuhan ekonomi dan belanja modal pada periode tahun tertentu dipengaruhi oleh IPM, pertumbuhan ekonomi dan belanja modal tahun sebelumnya. Hasil granger causality test menemukan adanya unidirectional causality dari IPM ke pertumbuhan ekonomi.
\end{abstract}

Kata kunci: Indeks pembangunan manusia, pertumbuhan ekonomi, belanja modal, regresi panel, panel vector autorgression (PVAR), dan granger causality test. 


\section{PENDAHULUAN}

Kesejahteraan masyarakat merupakan tujuan dari pembangunan, namun pada kenyataannya selama ini pembangunan hanya ditujukan untuk mengejar target pertumbuhan ekonomi. Sementara itu, pertumbuhan ekonomi yang tinggi belum tentu menjamin peningkatan kesejahteraan masyarakat secara umum. Pembangunan ekonomi di suatu daerah bisa dikatakan berhasil apabila pertumbuhan ekonomi juga sejalan dengan peningkatan kesejahteraan masyarakat yang diukur dengan Indeks Pembangunan Manusia (IPM).

Publikasi United Nations Development Programme (UNDP) mengenai Human Development Report tahun 1996 tentang konsep indeks pembangunan manusia, menyatakan konsep itu mengandung empat unsur utama, yang meliputi produktivitas (productivity), pemerataan (equity), kesinambungan (sustainnability) serta pemberdayaan (empowerment). Selanjutnya IPM dilihat berdasarkan tiga faktor utama yaitu faktor kesehatan, pendidikan dan pendapatan. Pengukuran IPM memakai tiga indikator dasar, yaitu usia, ilmu yang dimiliki, dan kelayakan dalam pemenuhan kebutuhan hidup. Ketiga unsur tersebut tidak dapat berdiri sendiri akan tetapi saling berhubungan satu sama lain (Sari, 2016).

Indikator dari tingkat kesejahteraan masyarakat kabupaten di Aceh tentunya juga bisa diukur menggunakan IPM. Seiring proses pembangunan di Aceh, maka IPM pada masing-masing kabupaten juga relatif berbeda. Kabupaten yang dimaksud dalam kajian ini adalah kabupaten Aceh Tamiang, Aceh Tenggara, Gayo Lues dan Simelue. Pemilihan kabupaten tersebut didasarkan kepada pertimbangan bahwa keempat kabupaten merupakan daerah yang relatif jauh dari pusat pertumbuhan ekonomi di Aceh. Apalagi kabupaten Simelue dan Gayo Lues misalnya, selain merupakan kabupaten baru dan pecahan dari kabupaten induknya, kedua kabupaten itu tercatat sebagai tertinggal di Aceh. Tabel 1 menunjukkan trend perkembangan IPM keempat kabupaten tersebut selama periode tahun 2011-2015.

Berdasarkan Tabel 1 terlihat kabupaten dengan IPM tertinggi adalah Aceh Tamiang dengan rata-rata IPM selama periode tahun 2011-2015 sebesar 65,77\%. Sebaliknya kabupaten dengan IPM terendah adalah kabupaten Simelue dengan rata-rata 61,86\%. Adanya perbedaan IPM di empat kabupaten seperti ditunjukkan dalam Tabel 1, tentunya dapat dikaitkan dengan variabel ekonomi makro seperti pertumbuhan ekonomi dan belanja modal pemda (Sukirno, 2008).

Pertumbuhan ekonomi masing-masing kabupaten juga relatif berbeda satu sama lain. Hal ini ditunjukkan oleh Produk Domestik Regional Bruto (PDRB). Selama periode tahun 2011-2015 daerah dengan PDRB paling tinggi adalah Kabupaten Gayo Lues, dan daerah dengan PDRB terendah adalah kabupaten Aceh Tenggara. Perbedaan PDRB tersebut mengindikasikan bahwa nilai barang dan jasa yang dihasilkan oleh perekonomian daerah tersebut juga berbeda.

Alokasi anggaran pemerintah daerah dalam bentuk belanja modal juga relatif berbeda antar daerah. Belanja modal yang dimaksudkan adalah belanja modal per kapita. Selama periode tahun 2015, daerah dengan alokasi belanja modal per kapita paling tinggi yaitu kabupaten Gayo Lues, disusul Simelue di urutan kedua dan Aceh Tamiang di urutan ketiga. Sebaliknya Aceh Tenggara merupakan daerah dengan belanja modal per kapita terendah di antara empat kabupaten tersebut.

Selama ini kajian mengenai keterkaitan antara pertumbuhan ekonomi, indek pembangunan manusia (IPM) dan alokasi belanja pemerintah daerah dalam bentuk belanja modal belum banyak diungkapkan peneliti, terutama di dalam lingkup perekonomian kabupaten di Aceh. Riset-riset terdahulu umumnya menggunakan data time series dengan menganalisis variabel ekonomi makro Aceh secara keseluruhan. Penelitian ini menggunakan data panel empat kabupaten di Aceh dengan fokus analisis hubungan fungsional antara IPM dengan pertumbuhan ekonomi dan belanja modal, dan menganalisis hubungan kausalitas antara ketiga variabel itu. 
Tabel 1. Peningkatan IPM pada 4 Kabupaten di Provinsi Aceh

\begin{tabular}{ccccccc}
\hline \multirow{2}{*}{ Kabupaten } & $\mathbf{9}$ Peningkatan IPM & \multirow{2}{*}{ Rata-Rata } \\
\cline { 2 - 6 } & $\mathbf{2 0 1 1}$ & $\mathbf{2 0 1 2}$ & $\mathbf{2 0 1 3}$ & $\mathbf{2 0 1 4}$ & $\mathbf{2 0 1 5}$ & \\
\hline Aceh Tamiang & 64,89 & 65,21 & 65,56 & 66,09 & 67,03 & 65,77 \\
\hline Aceh Tenggara & 64,27 & 64,99 & 65,55 & 65,90 & 66,77 & 65,49 \\
\hline Gayo Lues & 61,91 & 62,84 & 63,22 & 63,34 & 63,67 & 62,99 \\
\hline Simelue & 61,03 & 61,25 & 61,68 & 62,18 & 63,16 & 61,86 \\
\hline Aceh Tamiang & 64,89 & 65,21 & 65,56 & 66,09 & 67,03 & 65,77 \\
\hline Aceh Tenggara & 64,27 & 64,99 & 65,55 & 65,90 & 66,77 & 65,49 \\
\hline Gayo Lues & 61,91 & 62,84 & 63,22 & 63,34 & 63,67 & 62,99 \\
\hline
\end{tabular}

Sumber: BPS Aceh, tahun 2017.

\section{Produk Domestik Regional Bruto (PDRB)}

PDRB merupakan cerminan potensi dan aktivitas perekonomian yang dihitung berdasarkaan total seluruh output produksi kotor dalam suatu wilayah, sebagaimana dimaksud dalam UU No. 33 tahun 2004 tentang Perimbangan Keuangan antara Pemerintah Pusat dan Daerah. Menurut Sukirno (2000), PDRB meupakan seluruh nilai tambah yang timbul dari berbagai aktivitas ekonomi di suatu wilayah, tanpa memerhatikan pemilikan atas faktor produksi, apakah milik penduduk wilayah tersebut ataukah milik penduduk wilayah lain.

PDRB menurut BPS didefinisikan sebagai jumlah nilai tambah yang dihasilkan oleh seluruh unit usaha dalam suatu wilayah, atau merupakan jumlah seluruh nilai barang dan jasa akhir yang dihasilkan oleh seluruh unit ekonomi di suatu wilayah. PDRB atas harga berlaku menggambarkan nilai tambah barang dan jasa yang dihitung menggunakan harga pada setiap tahun, sedangkan PDRB atas dasar harga konstan menunjukkan nilai tambah barang dan jasa yang dihitung menggunakan harga pada tahun tertentu sebagai dasar, dimana dalam perhitungan ini digunakan harga konstan tahun 2010. PDRB atas dasar harga kosntan digunakan untuk mengetahui pertumbuhan ekonomi dari tahun ke tahun. Sedangkan menurut BPS, PDRB atas dasar harga berlaku digunakan untuk menunjukkan besarnya struktur perekonomian dan peranan sektor ekonomi.
Kuncoro (2001) menyatakan bahwa pendekatan pembangunan tradisional lebih dimaknai sebagai pembangunan yang lebih memfokuskan pada peningkatan PDRB suatu provinsi, kabupaten dan kota. Sedangkan pertumbuhan ekonomi dapat dilihat dari peningkatan angka PDRB. Saat ini umumnya PDRB baru dihitung berdasarkan dua pendekatan, yaitu dari sisi sektoral/lapangan usaha dan dari sisi penggunaan. Selanjutnya PDRB juga dihitung berdasarkan harga berlaku dan harga konstan. Total PDRB menunjukkan jumlah seluruh nilai tambah yang dihasilkan oleh penduduk dalam periode tertentu.

\section{Belanja Modal}

Belanja modal menurut Cristy dan Adi (2009) dimaksudkan untuk mendapatkan aset tetap pemerintah daerah, yakni peralatan, bangunan, infrastruktur, dan harta tetap lainnya. Belanja modal mempunyai kesamaan dimensi dengan definisi dari belanja pembangunan. Belanja pembangunan diartikan sebagai pengeluaran yang manfaatnya cenderung melebihi satu tahun anggaran dan menambah aset atau kekayaan bagi daerah, yang selanjutnya akan menambah anggaran rutin untuk biaya operasional dan pemeliharaannya.

Belanja modal dimaksudkan untuk mendapatkan aset tetap pemerintah daerah yaitu peralatan, bangunan, infrastruktur dan harta tetap lainnya. Secara teoritis, ada tiga cara untuk memperoleh aset tetap tersebut. 
yakni dengan membangun sendiri, menukarkan dengan aset tetap lain, dan membeli. Namun biasanya cara yang dilakukan dalam pemerintahan adalah dengan cara membeli. Proses pembelian yang dilakukan umumnya melalui sebuah proses lelang atau tender yang cukup rumit.

\section{Indeks Pembangunan Manusia}

Menurut Mankiw (2003), modal manusia adalah pengetahuan dan kemampuan yang diperoleh oleh para pekerja melalui pendidikan mulai dari program untuk anakanak sampai dengan pelatihan dalam pekerjaan (on the job training) untuk para pekerja dewasa. Seperti halnya dengan modal fisik, modal manusia dapat meningkatkan kemampuan untuk memproduksi barang dan jasa. Untuk meningkatkan level modal manusia dibutuhkan investasi dalam bentuk guru, perpustakaan dan waktu belajar.

Indeks pembangunan manusia (IPM) merupakan indikator strategis yang banyak digunakan untuk melihat upaya dan kinerja program pembangunan secara menyeluruh di suatu wilayah. Dalam hal ini, IPM dianggap sebagai gambaran dari hasil program pembangunan yang telah dilakukan. Juga, kemajuan program pembangunan dalam suatu periode dapat diukur dan ditunjukkan oleh besaran IPM pada awal dan akhir periode tersebut. IPM merupakan ukuran untuk melihat dampak kinerja pembangunan wilayah dengan dimensi yang sangat luas, karena memperlihatkan kualitas penduduk suatu wilayah dalam hal harapan hidup, intelelektualitas dan standar hidup layak.

Pada implementasi perencanaan aspek pembangunan, IPM juga berfungsi dalam memberikan tuntunan menentukan prioritas perumusan kebijakan dan penentuan program pembangunan. Ini merupakan juga tuntunan di dalam mengalokasikan anggaran yang sesuai dengan kebijakan umum yang telah ditentukan oleh pembuat kebijakan dan pengambil keputusan. IPM merupakan indeks komposit yang dihitung sebagai rata-rata sederhana dari tiga indeks yang menggambarkan kemampuan dasar manusia dalam memperluas pilihan-pilihan, yaitu; (1)Indeks
Harapan Hidup; (2)Indeks Pendidikan; dan, (3)Indeks Standar Hidup Layak.

\section{Keterkaitan Pertumbuhan Ekonomi atas Indeks Pembangunan Manusia}

Tingkat pendapatan dan IPM memiliki korelasi yang luas. Namun pertumbuhan pendapatan tak secara otomatis meningkatkan IPM. Demikian pula, perbaikan kesehatan dan pendidikan yang menyebabkan peningkatan IPM tidak selalu mengarah pada peningkatan pendapatan. Hal ini disebabkan sumber daya yang dihasilkan oleh pertumbuhan ekonomi tidak dapat digunakan untuk mempromosikan perbaikan indikator lainnya (Dewi, 2017).

Selain itu, struktur dan proses yang terjadi di masyarakat tidak dapat memberikan manfaat bagi kaum miskin. Misalnya, berbagai peningkatan hasil panen hanya menguntungkan pemilik tanah dan bukan tenaga kerja. Akan tetapi, kondisinya bisa berubah. Masyarakat kategori miskin dapat memperoleh manfaat ganda dari pertumbuhan pendapatan serta peningkatan IPM jika pemerintah mau menggunakan manfaat dari pertumbuhan untuk membiayai pelayanan kesehatan dan akses pendidikan masyarakat miskin tersebut. Selain itu, struktur dan proses yang ada dimasyarakat sudah tepat, sehingga manfaat pertumbuhan ekonomi juga dinikmati kaum miskin. Menurut World Development Report, kemajuan pada kedua bidang akan saling memperkuat satu sama lain (Kanbur \& Squire, 1999).

Adanya keterkaitan antara pertumbuhan ekonomi dengan indek pembangunan manusia secara empiris sudah dibuktikan oleh banyak peneliti. Mahani et al. (2014) menyimpulkan bahwa hubungan antar pertumbuhan ekonomi dengan indeks pembangunan manusia tidak memiliki hubungan timbal balik. Penelitian Srinivasan (2013) menemukan bahwa adanya hubungan searah dari pertumbuhan ekonomi ke belanja pemerintah pada jangka pendek dan jangka panjang. Selanjutnya Idenyi et al. (2016) dalam penelitian mereka di Nigeria juga menyimpulkan bahwa terdapat hubungan jangka panjang antara pertumbuhan ekonomi dan indek pembangunan manusia. 


\section{Keterkaitan Belanja Modal terhadap Indeks Pembangunan Manusia}

Pengalokasian dana belanja modal untuk kesejahteraan khususnya di bidang pendidikan, diharapkan berkontribusi lebih besar untuk kemajuan daerah serta upaya mencerdaskan kehidupan bangsa. Belanja modal ini dapat berupa pembangunan gedung, sarana dan prasarana yang memadai untuk pengamanan bersekolah sehingga kemajuan dalam pendidikan juga akan meningkatkan kualitas pembangunan manusia (Cristy \& Adi, 2009). Kesejahteraan masyarakat dapat diwujudkan dengan pemenuhan kebutuhan dasar seperti kesehatan, pendidikan, dan infrastruktur. Pemenuhan akan kebutuhan dasar akan meningkatkan kualitas sumber daya manusia. Sumber daya yang berkualitas akan mampu memberikan konstribusi dalam kemajuan teknologi yang lebih mutakhir sehingga dapat meningkat efesiensi produksi. Pengembangan sumberdaya manusia dapat dilakukan dengan perbaikan kualitas model manusia (Mankiw, 2008).

Belanja modal merupakan salah satu cara untuk mewujudkan tujuan ekonomi daerah yaitu meningkatkan kesejahteraan dan meningkatkan pelayanan kepada masyarakat yaitu dengan menyediakan fasilitas yang bersinggungan langsung dengan pelayanan publik. Adanya pengaruh belanja modal terhadap indek pembangunan manusia secara empiris sudah dibuktikan oleh beberapa peneliti sebelumnya (Mirza, 2011; Ariza, 2016; Sari, 2017). Innocent et al. (2017) dalam penelitian mereka di Nigeria juga menyimpulkan bahwa belanja modal berpengaruh positif dan signifikan terhadap pertumbuhan ekonomi. Sebelumnya Suryati (2015) juga menemukan bahwa Semua belanja derah berdasarkan belanja modal berpengaruh positif tapi tidak signifikan terhadap Indeks Pembangunan Manusia.

\section{METODE PENELITIAN}

\section{Ruang Lingkup Penelitian, Jenis dan Sumber Data}

Penelitian ini mencakup satu variabel dependen dan dua variabel independen. Variabel dependen yang digunakan adalah
Indeks pembangunan Manusia (IPM); dan variabel independen yang digunakan adalah Pertumbuhan Ekonomi serta Belanja Modal.

Data yang digunakan adalah data sekunder dalam bentuk panel data empat kabupaten di Aceh terdiri dari kabupaten Aceh Tamiang, kabupaten Gayo Lues, kabupaten Aceh Tenggara, dan kabupaten Simelue. Data tersebut adalah data tahunan selama periode tahun 2011-2015. Data diperoleh dari Badan Pusat statistik (BPS) Provinsi Aceh dan instansi terkait lainnya.

\section{Operasional Variabel}

Variabel yang dioperasionalkan dalam penelitian ini terdiri dari Indek Pembangunan Manusia (IPM), pertumbuhan ekonomi dan belanja modal. IPM adalah indeks komposit yang dihitung sebagai rata-rata sederhana dari 3 (tiga) indeks (pendidikan, kesehatan, pendapatan/daya beli) yang menggambarkan kemampuan dasar manusia dalam memperluas pilihan-pilihan dihitung dalam satuan persen.

Pertumbuhan ekonomi adalah derajat peningkatan nilai barang dan jasa yang dihasilkan oleh masyarakat dalam suatu daerah. Pengukuran pertumbuhan ekonomi menggunakan PDRB per kapita berdasarkan harga konstan tahun 2010 dengan satuan rupiah. Selanjutnya belanja modal adalah alokasi belanja modal oleh pemerintah daerah pada periode tahun tertentu diukur dengan belanja modal per kapita dihitung dengan satuan rupiah.

\section{Model Analisis Data}

Model analisis yang digunakan dalam kajian ini terdiri dari regresi panel, panel vector autoregressive (PVAR), Impulse Respons Function (IRF), Variance Decomposition dan Granger Causality Test. Adapun model regresi panel dalam penelitian ini diformulasikan sebagai berikut:

$$
\begin{aligned}
& \log \left(\mathrm{IPM}_{\mathrm{it}}\right)=\alpha+ \beta_{1} \log \left(\mathrm{PDRB}_{\mathrm{it}}\right)+\beta_{2} \\
& \log \left(\mathrm{BM}_{\mathrm{it}}\right)+\epsilon_{\mathrm{it}}
\end{aligned}
$$

dimana $\log (\mathrm{IPM})$ merupakan log Indeks Pembangunan Manusia, $\log (\mathrm{PDRB})$ adalah 
$\log$ PDRB perkapita sebagai tolak ukur pertumbuhan Ekonomi, $\log (\mathrm{BM})$ adalah $\log$ belanja modal per kapita, $\alpha$ adalah konstanta, $\beta_{1}$ dan $\beta_{2}$ adalah koefisien regresi, $i$ adalah provinsi ke-i, $t$ adalah tahun pengamatan, dan $\epsilon_{\text {it }}$ adalah error term.

Model Vector Autoregressive (VAR) biasanya digunakan untuk memproyeksikan sistem variabel-variabel runut waktu dan untuk menganalisis dampak dinamis dari faktor gangguan yang terdapat dalam sistem variabel tersebut. Penggunaan VAR data panel dimaksudkan untuk menganalisis hubungan kausalitas antara pertumbuhan ekonomi, belanja modal dan Indeks Pembangunan Manusia (IPM), yang dalam penelitian ini diformulasi dalam tiga persamaan struktural:

$$
\begin{aligned}
\log (\mathrm{IPM})_{\mathrm{it}}= & \alpha_{0}+\alpha_{1} \log \left(\mathrm{IPM}_{\mathrm{it}-1}\right)+\alpha_{2} \log \left(\mathrm{IPM}_{\mathrm{it}-2}\right)+\alpha_{1} \log \left(\mathrm{PDRB}_{\mathrm{it}-1}\right) \\
& +\alpha_{2} \log \left(\mathrm{PDRB}_{\mathrm{it}-2}\right)+\alpha_{1} \log \left(\mathrm{BM}_{\mathrm{it}-1}\right)+\alpha_{2} \log \left(\mathrm{BM}_{\mathrm{it}-2}\right)+\epsilon \\
\log (\mathrm{PDRB})_{\mathrm{it}}= & \alpha_{0}+\alpha_{1} \log \left(\mathrm{IPM}_{\mathrm{it}-1}\right)+\alpha_{2} \log \left(\mathrm{IPM}_{\mathrm{it}-2}\right)+\alpha_{1} \log \left(\mathrm{PDRB}_{\mathrm{it}-1}\right) \\
& +\alpha_{2} \log \left(\mathrm{PDRB}_{\mathrm{it}-2}\right)+\alpha_{1} \log \left(\mathrm{BM}_{\mathrm{it}-1}\right)+\alpha_{2} \log \left(\mathrm{BM}_{\mathrm{it}-2}\right)+\epsilon \\
\log (\mathrm{BM})_{\mathrm{it}}= & \alpha_{0}+\alpha_{1} \log \left(\mathrm{IPM}_{\mathrm{it}-1}\right)+\alpha_{2} \log \left(\mathrm{IPM}_{\mathrm{it}-2}\right)+\alpha_{1} \log \left(\mathrm{PDRB}_{\mathrm{it}-1}\right) \\
& +\alpha_{2} \log \left(\mathrm{PDRB}_{\mathrm{it}-2}\right)+\alpha_{1} \log \left(\mathrm{BM}_{\mathrm{it}-1}\right)+\alpha_{2} \log \left(\mathrm{BM}_{\mathrm{it}-2}\right)+\epsilon
\end{aligned}
$$

dimana $\log (\mathrm{IPM})$ adalah $\log$ indeks pembangunan manusia, $\log (\mathrm{PDRB})$ adalah log PDRB perkapita sebagai tolak ukur pertumbuhan ekonomi, $\log (\mathrm{BM})$ adalah $\log$ belanja modal perkapita, $\mathrm{i}$ adalah kabupaten, $\mathrm{t}$ adalah tahun, $\alpha$ adalah kontansta, dan $\epsilon$ adalah term of error. Sebagai pelengkap dalam penggunaan panel VAR sebagai alat analisis data, analisis terhadap arah hubungan kausalitas antar variabel menggunakan Granger Causality Test.

\section{HASIL ANALISIS}

Langkah pertama dalam penggunaan regresi panel adalah menentukan metode regresi yang dinilai tepat di antara beberapa alternatif pilihan metode regresi panel (fixed effect, random effect dan common effect). Hasil uji Chow test dan Hausman test merekomendasikan bahwa model fixed effect merupakan model terbaik yang digunakan dalam penelitian. Oleh sebab itu, penelitian ini difokuskan pada analisa dari hasil regresi data panel dengan metode fixed effect.

Berdasarkan hasil regresi panel dalam Tabel 2, dijelaskan beberapa analisa statistik terkait tingkat signifikansi antar variabel secara simultan dan parsial, maupun nilai $\mathrm{R}^{2}$ dari hasil regresi yang menggambarkan kemampuan variabel independen untuk menjelaskan variabel dependennya.

\section{Hasil Uji Signifikansi Simultan (Uji F)}

Tabel 2 menunjukan besarnya F-statistik sebesar 166,1492 dan nilai probabilitas $\mathrm{F}$ sebesar 0,00 . Oleh karena itu nilai prob $\mathrm{F}$ (statistic) sebesar 0,00 lebih kecil daripada tingkat signifikan 0,05 sehingga dapat disimpulkan pertumbuhan ekonomi (PDRB) dan belanja modal terbukti secara simultan berpengaruh signifikan terhadap indeks pembangunan manusia dan model estimasi layak digunakan untuk menjelaskan pengaruh pertumbuhan ekonomi (PDRB) dan belanja modal atas indeks pembangunan manusia.

\section{Hasil Uji Signifikansi Parsial (Uji t)}

Hasil uji $\mathrm{t}$ menyimpulkan nilai prob variabel $\log (\mathrm{PDRB})$ sebesar 0,00 yang lebih kecil dari 0,05 sehingga variabel bebas berpengaruh signifikan terhadap variabel terikat, yaitu $\log ($ IPM). Dengan kata lain, pertumbuhan ekonomi secara parsial memiliki pengaruh signifikan atas indeks pembangunan manusia pada taraf keyakinan $95 \%$. Selanjutnya nilai prob untuk variabel bebas $\log (\mathrm{BM})$ sebesar 0.2702 yang lebih besar dari 0,05 sehingga variabel bebas $\log (\mathrm{BM})$ tidak berpengaruh signifikan terhadap variabel terikat $\log (\mathrm{IPM})$ pada alpha $5 \%$. Atau dengan kata lain belanja modal secara parsial tidak berpengaruh signifikan terhadap indeks pembangunan manusia. 
Tabel 2. Hasil Vector Autoregressive (VAR)

\begin{tabular}{lccc}
\hline & $\log (\mathbf{I P M})$ & $\log (\mathbf{P D R B})$ & $\log (\mathbf{B M})$ \\
\hline $\log (\mathbf{I P M}(-1))$ & 1.367 & -0.606 & -6.235 \\
& $(0.449)$ & $(0.638)$ & $(30.099)$ \\
& {$[3.043]$} & {$[-0.949]$} & {$[-0.207]$} \\
\hline $\log (\mathbf{I P M}(-2))$ & -0.361 & 0.410 & 3.194 \\
& $(0.489)$ & $(0.696)$ & $(32.827)$ \\
& {$[-0.738]$} & {$[0.589]$} & {$[0.097]$} \\
\hline $\log (\mathbf{P D R B}(-1))$ & -0.0143 & 0.691 & 10.396 \\
& $(0.319)$ & $(0.455)$ & $(21.433)$ \\
& {$[-0.045]$} & {$[1.521]$} & {$[0.485]$} \\
\hline $\log (\mathbf{P D R B}(-2))$ & 0.001 & 0.293 & -9.359 \\
& $(0.319)$ & $(0.454)$ & $(21.434)$ \\
& {$[0.003]$} & {$[0.644]$} & {$[-0.434]$} \\
\hline $\log ($ BM(-1)) & 0.005 & -0.007 & 0.935 \\
& $(0.003)$ & $(0.005)$ & $(0.223)$ \\
& {$[1.538]$} & {$[-1.454]$} & {$[4.183]$} \\
\hline Log(BM(-2)) & -0.005 & 0.005 & -0.266 \\
& $(0.002)$ & $(0.007)$ & $(0.328)$ \\
& {$[-1.115]$} & {$[0.750]$} & {$[-0.811]$} \\
\hline C & 0.207 & 1.133 & 0.099 \\
& $(0.476)$ & $(0.677)$ & $(31.921)$ \\
& {$[0.435]$} & {$[1.674]$} & {$[0.003]$} \\
\hline Adj. R-squared & 0.988 & 0.999 & 0.911 \\
\hline
\end{tabular}

Sumber: Data sekunder (diolah), tahun 2017.

\section{Panel Vector Autoregressive (VAR)}

Hasil analisis menunjukkan bahwa indeks pembangunan manusia pada periode tertentu secara nyata dipengaruhi oleh indeks pembangunan manusia periode sebelumnya. Dengan kata lain, indeks pembangunan manusia pada tahun tertentu berpengaruh positif dan signifikan terhadap indeks pembangunan manusia tahun berikutnya. Hal ini ditunjukkan oleh nilai koefisien regresi sebesar 1.367 dan nilai t-statistik sebesar 3.042. Sebaliknya, dampak dari indeks pembangunan manusia terhadap dirinya dalam horizon waktu 2 periode adalah negatif dan tidak signifikan dengan nilai koefisien regresi sebesar -0.361 dan nilai t-statistik sebesar -0.738. Pertumbuhan ekonomi berpengaruh negatif dan tidak signifikan terhadap indeks pembangunan manusia dalam horizon waktu 1 periode, hal ini ditunjukkan oleh koefisien regresi sebesar -0.014 dan nilai t-statistik -0.045.

Sebaliknya, dampak pertumbuhan ekonomi atas indeks pembangunan manusia dalam horizon waktu 2 periode adalah berpengaruh positif namun tidak signifikan, hal ini ditunjukkan oleh koefisien regresi sebesar 0.001 dan nilai t-statistik -0.003 . Belanja modal berpengaruh positif dan tidak signifikan terhadap indeks pembangunan manusia dalam horizon waktu 1 periode, hal ini ditunjukkan oleh koefisien regresi sebesar 0.005 dan nilai t-statistik 1.539. Namun dampak belanja modal terhadap dirinya dalam horizon waktu 1 periode adalah positif dan signifikan dengan nilai koefisien regresi 
sebesar 0.934 dan nilai t-statistik sebesar 4.183. Belanja modal diperoleh berpengaruh negatif dan tidak signifikan terhadap indeks pembangunan manusia dalam horizon waktu 2 periode, hal ini ditunjukkan oleh koefisien regresi sebesar -0.005 dan nilai t-statistik sebesar -1.115.

Nilai koefisien determinasi (adjusted $R$ square) dengan cara menempatkan indeks pembangunan manusia pada periode tertentu sebagai fungsi dari indeks pembangunan manusia, pertumbuhan ekonomi dan belanja modal pada tahun sebelumnya menunjukkan angka sebesar 0.974. Hal ini berarti bahwa sebesar 97,4\% indeks pembangunan manusia dalam periode tahun tertentu dapat dijelaskan indeks pembangunan manusia, pertumbuhan ekonomi dan belanja modal pada periode 1 dan 2 tahun sebelumnya. Besarnya peran indeks pembangunan manusia, pertumbuhan ekonomi dan belanja modal itu sendiri dalam menjelaskan perubahan pada indeks pembangunan manusia itu sendiri juga diperkuat oleh nilai F-statistik sebesar 72.358. Hasil vector Autoregression ditunjukkan dalam Tabel 2.

\section{Impulse Respon Functions}

Impulse Respon Functions (IRF) menunjukkan respon suatu variabel endogen terhadap perubahan endogen lainnya yang ada dalam suatu sistem dinamis VAR. IRF dapat digunakan untuk meneliti pengaruh satu standar deviasi kejutan dari satu variabel inovasi terhadap nilai variabel endogen saat ini atau untuk waktu yang akan datang. Variabel inovasi yang dimaksudkan dalam penelitian adalah indeks pembangunan manusia, pertumbuhan ekonomi dan belanja modal ketika variabel tersebit ditempatkan pada variabel penjelas (Amri, 2017).

Pada periode pertama, hampir tidak ada respon indek pembangunan manusia terhadap pertumbuhan ekonomi, untuk kemudian pada periode kedua mulai ada respon dan respon tersebut cenderung bergerak negatif sampai periode kelima. Kemudian pada periode keenam, ketujuh, dan kedelapan mulai tidak ada respon hingga memasuki periode kesembilan dan kesepuluh mulai ada respon yang cenderung negatif. Respon indeks pembangunan manusia terhadap belanja modal menunjukkan bahwa respon Belanja modal ketika terjadi shock dengan variabel indeks pembangunan manusia memberikan respon yang positif periode pertama sampai dengan periode keenam dan selanjutnya di respon negatif sampai tahun periode ke sepuluh.

Respons pertumbuhan ekonomi terhadap indeks pembangunan manusia menunjukkan bahwa respon Indeks Pembangunan Manusia ketika terjadinya shock dengan variabel pertumbuhan ekonomi mula-mula memberikan respon yang positif pada periode pertama, kemudian pada periode selanjutnya memberikan respon yang negatif. Respons pertumbuhan ekonomi terhadap belanja modal, menunjukkan bahwa respon belanja modal ketika terjadinya shock dengan variabel pertumbuhan ekonomi mula-mula memberikan respon yang positif pada periode pertama kemudian pada periode selanjutnya memberikan respon yang negatif.

Respon belanja modal terhadap indeks pembangunan manusia menunjukkan bahwa respon indeks pembangunan manusia ketika terjadinya shock dengan variabel belanja modal terus memberikan respon yang negatif dari tahun ke tahun. Sedangkan respons belanja modal atas pertumbuhan ekonomi, menunjukkan respon pertumbuhan ekonomi, dimana ketika terjadi shock dengan variabel belanja modal mula-mula memberikan respon yang negatif dari periode periode pertama sampai dengan periode ketiga dan selanjutnya memberikan respon yang positif.

\section{Variance Decomposition}

Variance Decomposition memisahkan variasi perubahan shock dari setiap variabel atas variabel lain. Variance Decomposition menunjukkan besarnya sumbangan pengaruh suatu variabel perubahan terhadap variabel lain dalam model. Hasil analisis Variance Decomposition pada variabel-variabel IPM, pertumbuhan ekonomi, dan belanja modal dapat dilihat pada Tabel 3 . 
Tabel 3. Hasil Uji Variance Decomposition

\begin{tabular}{ccccc}
\hline \multicolumn{5}{c}{ Variance Decomposition of $\log (\mathrm{IPM})$} \\
\hline Period & S.E. & $\log (\mathbf{I P M})$ & $\log (\mathbf{P D R B})$ & $\log (\mathbf{B M})$ \\
\hline 1 & 0.004 & 100.00 & 0.000 & 0.000 \\
\hline 2 & 0.006 & 97.455 & 1.481 & 1.063 \\
\hline 3 & 0.008 & 96.603 & 1.701 & 1.695 \\
\hline 4 & 0.010 & 96.962 & 1.494 & 1.542 \\
\hline 5 & 0.012 & 97.591 & 1.216 & 1.192 \\
\hline 6 & 0.014 & 98.076 & 1.007 & 0.915 \\
\hline 7 & 0.015 & 98.391 & 0.880 & 0.727 \\
\hline 8 & 0.017 & 98.582 & 0.821 & 0.596 \\
\hline 9 & 0.018 & 98.687 & 0.811 & 0.500 \\
\hline 10 & 0.020 & 98.735 & 0.837 & 0.427 \\
\hline
\end{tabular}

Variance Decomposition of $\log (\mathrm{PDRB})$ :

\begin{tabular}{ccccc}
\hline Period & S.E. & $\log (\mathbf{I P M})$ & $\log (\mathbf{P D R B})$ & $\log (\mathbf{B M})$ \\
\hline 1 & 0.006 & 0.916 & 99.083 & 0.000 \\
\hline 2 & 0.008 & 1.285 & 97.473 & 1.241 \\
\hline 3 & 0.010 & 1.910 & 95.834 & 2.255 \\
\hline 4 & 0.012 & 4.208 & 93.113 & 2.677 \\
\hline 5 & 0.014 & 8.342 & 89.000 & 2.656 \\
\hline 6 & 0.015 & 14.056 & 83.494 & 2.449 \\
\hline 7 & 0.016 & 20.606 & 77.201 & 2.192 \\
\hline 8 & 0.018 & 27.373 & 70.686 & 1.939 \\
\hline 9 & 0.021 & 33.969 & 64.320 & 1.709 \\
\hline 10 & 0.023 & 40.193 & 58.301 & 1.505 \\
\hline
\end{tabular}

Variance Decomposition of $\log (\mathrm{BM})$ :

\begin{tabular}{ccccc}
\hline Period & S.E. & $\log (\mathbf{I P M})$ & $\log (\mathbf{P D R B})$ & $\log (\mathbf{B M})$ \\
\hline 1 & 0.302 & 56.864 & 22.630 & 20.505 \\
\hline 2 & 0.409 & 63.932 & 15.110 & 20.957 \\
\hline 3 & 0.456 & 68.476 & 12.407 & 19.116 \\
\hline 4 & 0.476 & 70.829 & 11.405 & 17.764 \\
\hline 5 & 0.488 & 72.095 & 10.993 & 16.911 \\
\hline 6 & 0.498 & 73.021 & 10.720 & 16.258 \\
\hline 7 & 0.508 & 73.921 & 10.446 & 15.632 \\
\hline 8 & 0.519 & 74.853 & 10.155 & 14.991 \\
\hline 9 & 0.531 & 75.800 & 9.861 & 14.338 \\
\hline 10 & 0.544 & 76.739 & 9.576 & 13.684 \\
\hline
\end{tabular}

Cholesky Ordering: $\log (\mathrm{IPM}) \log (\mathrm{PDRB}) \log (\mathrm{BM})$

Sumber: Data sekunder (diolah), tahun 2017. 
Tabel 4. Hasil Granger Causality Test

\begin{tabular}{lcc}
\hline \multicolumn{1}{c}{ Null Hypothesis: } & F-Statistic & Prob. \\
\hline Log(PDRB) does not Granger Cause $\log (\mathrm{IPM})$ & 0.3709 & 0.5530 \\
\hline Log(IPM) does not Granger Cause $\log (\mathrm{PDRB})$ & 10.096 & 0.0073 \\
\hline Log(BM) does not Granger Cause $\log (\mathrm{IPM})$ & 1.3080 & 0.2734 \\
\hline Log(IPM) does not Granger Cause $\log (\mathrm{BM})$ & 0.6921 & 0.4205 \\
\hline Log(BM) does not Granger Cause $\log (\mathrm{PDRB})$ & 0.7406 & 0.4051 \\
\hline Log(PDRB) does not Granger Cause $\log (\mathrm{BM})$ & 2.1122 & 0.1698 \\
\hline
\end{tabular}

Sumber: Data sekunder (diolah), tahun 2017.

Hasil analisis menyatakan bahwa Variance Decomposition dari variabel Indeks Pembangunan manusia menjelaskan bahwa pada periode pertama dipengaruhi oleh variabel itu sendiri atau $100 \%$, namun pada periode kedua sampai dengan periode kesepuluh nilainya terus menurun hingga menjadi $98.73 \%$.

Hasil analisis menyatakan bahwa variance decomposition dari variabel pertumbuhan ekonomi menjelaskan bahwa pada periode pertama dipengaruhi oleh variabel itu sendiri yaitu $99.08 \%$, namun pada periode kedua sampai dengan periode kesepuluh nilainya terus menurun hingga menjadi $58.30 \%$.

Hasil analisis menyatakan bahwa variance decomposition dari variabel belanja modal menjelaskan pada periode pertama dipengaruhi variabel indeks pembangunan manusia sebesar $56.86 \%$, dan pada periode kedua sampai dengan periode ke-10 nilainya terus meningkat hingga menjadi $76.73 \%$.

\section{Uji Kausalitas}

Hasil uji granger causality test antara IPM, Pertumbuhan Ekonomi, dan Belanja Modal bisa dilihat pada Tabel 4. Berdasarkan hasil Tabel 4 dapat diketahui adanya kausalitas satu arah (unidirectional causality) dari Indeks Pembangunan (IPM) ke pertumbuhan ekonomi. Hal ini ditunjukkan oleh nilai probability sebesar 0,0073 . Sebaliknya tidak terdapat kausalitas dari pertumbuhan ekonomi kepada indeks pembangunan manusia pada nilai probability sebesar 0,5530. Selanjutnya hasil uji kausalitas antara belanja modal dengan indek pembangunan manusia (IPM) dan antara belanja modal dengan pertumbuhan ekonomi mengindikasikan tidak adanya hubungan kausalitas antara variabel-variabel tersebut.

\section{KESIMPULAN}

Berdasarkan hasil penelitian mengenai pengaruh pertumbuhan ekonomi dan belanja modal terhadap indeks pembangunan manusia, dapat disimpulkan beberapa hal.

Kesimpulan pertama, pertumbuhan ekonomi berpengaruh positif dan signifikan terhadap peningkatan indeks pembangunan manusia (IPM). Hal ini berarti pada saat pertumbuhan ekonomi meningkat maka persentase indeks pembangunan manusia juga akan mengalami peningkatan. Sebaliknya, pada saat pertumbuhan ekonomi menurun maka persentase indeks pembangunan manusia juga mengalami penurunan. Dengan kata lain, setiap peningkatan pertumbuhan ekonomi sebesar 1\% akan meningkatkan persentase indeks pembangunan manusia sebesar $0.29 \%$; dan sebaliknya, penurunan pertumbuhan ekonomi sebesar $1 \%$ maka akan menurunkan persentase indeks pembangunan manusia sebesar $0.29 \%$.

Kesimpulan kedua, belanja modal berpengaruh positif tetapi tidak signifikan terhadap indeks pembangunan manusia (IPM). Artinya pada saat belanja modal meningkat IPM juga meningkat, namun peningkatan IPM akibat kenaikan belanja modal tidak signifikan. 
Kesimpulan ketiga, IPM pada periode tertentu secara nyata dipengaruhi oleh indeks pembangunan manusia periode sebelumnya. Sebaliknya, dampak indeks pembangunan manusia atas dirinya dalam horizon waktu 2 periode adalah negatif dan tidak signifikan. Pertumbuhan ekonomi berpengaruh negatif dan tidak signifikan terhadap indeks pembangunan manusia dalam horizon waktu 1 periode; sebaliknya, dampak pertumbuhan ekonomi terhadap indeks pembangunan manusia dalam horizon waktu 2 periode adalah berpengaruh positif namun tidak signifikan. Belanja modal berpengaruh positif dan tidak signifikan terhadap indeks pembangunan manusia dalam horizon waktu 1 periode. Namun dampak belanja modal terhadap dirinya dalam horizon waktu 1 periode adalah positif dan signifikan, dan belanja modal berpengaruh negatif dan tidak signifikan terhadap indeks pembangunan manusia dalam horizon waktu 2 periode.

Kesimpulan terakhir, hasil granger causality test menyimpulkan ada kausalitas satu arah (unidirectional causality) dari IPM ke pertumbuhan ekonomi. Artinya, IPM secara statistik mempengaruhi pertumbuhan ekonomi, tetapi sebaliknya tidak terdapat kausalitas dari pertumbuhan ekonomi ke indeks pembangunan manusia. Selanjutnya hasil uji kausalitas antara pertumbuhan ekonomi dan belanja modal mengindikasikan tidak adanya kausalitas antara kedua variabel tersebut.

Berdasarkan beberapa kesimpulan tersebut, maka direkomendasikan agar pemerintah daerah Kabupaten Aceh Tamiang, Gayo Lues, Aceh Tenggara dan Kabupaten Simelue seharusnya tidak hanya fokus pada kebijakan peningkatan pertumbuhan ekonomi melalui pembangunan infrastruktur fisik, tetapi juga seharusnya berorientasi pada peningkatan kualitas sumber daya manusia demi meningkatkan kesejahteraan masyarakat untuk mengurangi ketimpangan ekonomi.

Penelitian ini juga merekomendasikan agar pengalokasian anggaran daerah harus dapat dipastikan memberikan manfaat yang terukur bagi perbaikan kehidupan masyarakat di masa yang akan datang, terutama alokasi anggaran untuk penyediaan sarana dan prasarana pendidikan, kesehatan, maupun infrastruktur lainnya yang berkaitan dengan pelayanan publik. Dengan demikian, kebijakan pengalokasian anggaran daerah diharapkan mampu memberikan efek positif terhadap pembangunan manusia dan pertumbuhan ekonomi daerah.

\section{DAFTAR PUSTAKA}

Ali, S.A., Raza, H. dan Yousuf, M.U. 2012. The Role of Fiscal Policy in Human Development: The Pakistan's Perspective. The Pakistan Development Review. Vol. 51, No. 4, hal. 381-396.

Amri, K. 2017. Analisis Pertumbuhan Ekonomi dan Ketimpangan Pendapatan: Panel Data 8 Provinsi di Sumatera. Jurnal Ekonomi dan Manajemen Tekonologi. Vol. 1, No. 1, hal. 1-10.

Ariza, A. 2016. Pengaruh Pertumbuhan Ekonomi dan Belanja Modal Terhadap Indeks Pembangunan Manusia (IPM) dalam Perspektif Islam. Al-Maslahah Jurnal Ilmu Syariah. Vol. 12, No. 1, hal. 1-12.

Bau, Y.M. 2011. Pengaruh Dana Alokasi Umum dan Belanja Modal terhadap Indeks Pembangunan Manusia Kabupaten/Kota di Provinsi DIY Tahun 2005-2009. Skripsi. Yogyakarta: Program Studi Ekonomi Pembangunan UPN Veteran.

Cristy, F. A. dan Adi, P.H. 2009. Hubungan antara Dana Alokasi Umum, Belanja Modal dan Kualitas Pembangunan Manusia. Proceeding. The $3^{\text {rd }}$ National Conference UKWMS, Surabaya.

Davies, A. 2009. Human Development and The Optimal Size of Government. Journal of Socioeconomics. Vol. 35, No. 5, hal. 868-876.

Dewi, N. 2017. Pengaruh Kemiskinan dan Pertumbuhan Ekonomi Terhadap Indeks Pembangunan Manusia di Provinsi Riau. JOM Fekon Fakultas 
Ekonomi, Universitas Riau, Pekan Baru. Vol. 4, No. 1, hal. 870-882.

Fibriyani, V. 2017. Analisis Faktor-Faktor yang Mempengaruhi IPM dan Status Daerah Bermasalah Kesehatan (DBK) di Pulau Sumatera tahun 2013. Jurnal EMA (Ekonomi Manajemen Akuntansi). Vol. 4, No. 1, hal. 19-30.

Idenyi, O.S., Onyekachi, E. dan Ogbonna, S.O. 2016. Analysis of the Relationship between Human Capital Development and Economic Growth in Nigeria. European Journal of Accounting, Auditing, and Finance Research, Vol. 4, No. 3, hal. 56-71.

Innocent, K.C., Job, M.N., Okeke, A., dan Aondo, D.C. 2017. Government Expenditure and Human Capital Development in Nigeria. International Journal of Advance Studies in Economics and Public Sector Management. Vol. 5, No. 1, hal. 143158.
Mahani, C., Rahmanta dan Suriadi, A. 2014. Analisis Hubungan Kausalitan Pemabangunan Manusia dan Pertumbuhan Ekonomi Wilayah di Provinsi Sumatera Utara. Dinamika Ilmu. Vol. 4, No. 2, hal. 1-10.

Mirza, D.S. 2011. Pengaruh Kemiskinan, Pertumbuhan Ekonomi, dan Belanja Modal terhadap IPM Jawa Tengah. JEJAK. Vol. 4. No. 2, hal. 102-113.

Razmi, M.J. 2012. Investigating The Effect of Government Health Expenditure on HDI in Iran. Journal of Knowledge Management, Economics, \& Information Technology. Vol. 2, No. 5, hal. 1-13.

Sari, I.A.C.Y. 2016. Pengaruh Pendapatan Asli Daerah dan Belanja Modal Pada Indeks Pembangunan Manusia, EJurnal Akuntansi Universitas Udayana. Vol. 15, No. 3, hal. 24092438. 